\title{
Integrasi dan Fragmentasi Pengelolaan Sumber Daya Alam (Studi Kasus: Deforestrasi di Brazil)
}

\section{Tulus Warsito}

Jurusan IImu Hubungan Internasional, Fakultas IImu Sosial dan IImu Politik, Universitas Muhammadiyah Yogyakarta

Ringroad Barat Tamantirto, Kasihan, Bantul 55183

Email: tulusw_@yahoo.com

\begin{abstract}
This paper showed that regional autonomy, which gives an opportunity to region to fully manage natural resources, should be placed in the environmental dimension and position as a global issue. Environmental conditions will be increasingly threatened when environment and natural resources management is solely based on compliance income needs. By doing a comparison of natural resources management policies in Brazil, this paper tries to look at the direction and the relation between management of environmental issues and enforcement of regional autonomy in Indonesia. The case study of deforestation in Brazil show that environmental damage which occurs as a result of natural resources management (forest products) is not only a regional issue in Brazil, but also a national issue, even global issue. This example can be used as a comparison to determine how far regional autonomy should take cares natural resources issue like what happened in Brazil. Regional autonomy is the most fragmented efforts to natural resources, while the globally core of management is integrative efforts.

Keywords: Amazon, deforestation, local genius, illegal logging, regional autonomy
\end{abstract}

\begin{abstract}
Abstrak
Tulisan ini menunjukkan bahwa otonomi daerah - yang memberi peluang bagi daerah untuk secara penuh mengelola sumber daya alam (SDA) harus diletakkan dalam dimensi dan posisi lingkungan hidup sebagai sebuah isu global. Kondisi lingkungan hidup akan semakin terancam ketika pengelolaan lingkungan dan sumber daya alam hanya didasarkan pada pemenuhan kebutuhan pendapatan bagi suatu daerah. Dengan melakukan komparasi atas kebijakan penanganan SDA di Brazil, tulisan ini mencoba melihat arah dan relasi antara penanganan masalah lingkungan dan pemberlakukan Otonomi Daerah di Indonesia. Studi kasus Deforestasi di Brazil menunjukkan bahwa kerusakan lingkungan yang terjadi sebagai akibat dari pengelolaan SDA (hasil hutan) tidak saja merupakan perkara daerah (negara bagian) di Brazil, melainkan juga perkara nasional, bahkan merupakan persoalan global. Contoh ini dapat dipakai sebagai bahan pembanding untuk mengetahui sejauh mana otonomi daerah harus menangani persoalan SDA seperti yang terjadi di Brazil tersebut. Otonomi Daerah merupakan upaya paling fragmentatif terhadap SDA, sedangkan inti penanganan secara global merupakan upaya yang bersifat integratif.

Kata kunci: Amazon, deforestasi, local genius, pembalakan liar, otonomi daerah.
\end{abstract}

\section{PENDAHULUAN}

Membicarakan pengelolaan sumberdaya alam dalam kaitannya dengan otonomi daerah di era reformasi sekarang ini masih terasa sangat provokatif. Ada interpretasi yang stereotipikal yang beranggapan bahwa otonomi daerah seolah mengesahkan bupati atau walikota untuk mengelola apa saja yang ada di wilayah

mereka.

Anggapan tersebut tak seluruhnya benar, tetapi juga tidak semuanya salah. Banyak kasus menunjukkan adanya "politik portal", yaitu dengan dimunculkan peraturan daerah yang berlaku seperti "pajak jalanan" terhadap hasil bumi (atau hasil apa saja) dari wilayah 
lain yang melewati daerah kabupaten atau kotamadya kekuasaannya. Hasil batubara dari Ombilin (Sumatra Selatan) yang akan dikapalkan dari pelabuhan Panjang misalnya, yang harus melewati beberapa kabupaten di provinsi Lampung sebelum mencapai pelabuhan tersebut, kabarnya juga dipungut "cukai jalanan" semacam itu. Di sisi lain, pada konotasi yang lebih buruk, aliran sungai atau sistem drainase atau pembuangan sampah yang melewati daerah lain, juga dikenai "cukai" sejenis. Boleh jadi kabar itu hanya isu semata, tetapi kalaupun sesungguhnya benar-benar terjadi "logika bisnis"-nya memang bisa diterima akal, walaupun hal ini sebenarnya bukan semata-mata soal bisnis.

Rasanya wajar kalau hal tersebut terjadi pada era euforia reformasi. Mengingat reformasi telah berlangsung hampir genap satu dasawarsa, asumsi buruk terhadap raja kecil yang seolah menguasai daerahnya secara sepenuhnya itu, haruslah diubah dan diperbaiki. Sumber daya alam (SDA), termasuk di dalamnya adalah Bencana Alam (BA), sebaiknya diposisikan sebagai perkara bersama, baik untuk dikoordinasikan dengan pemerintah provinsi, pusat, bahkan kalau perlu dalam skala internasional.

Banyak kasus membuktikan bahwa tak mungkin pemerintah kabupaten atau kotamadya, bahkan pemerintah provinsi atau pemerintah pusat pun, dapat sepenuhnya mengelola SDA atau BA yang muncul di wilayahnya. Kasus "ekspor asap" yang terjadi setiap tahun di Sumatra maupun Kalimantan yang selalu menjadi cemoohan warga Singapura dan Malaysia misalnya, amat jelas menunjukkan hal tersebut. Luapan lumpur Lapindo di Sidoarjo, gempa bumi di Yogyakarta, apalagi Tsunami di Aceh Nangroe Darrussalam, adalah sebagian contoh yang menjukkan secara jelas bahwa kalau otonomi daerah harus diartikan secara naif menjadi "hak sepenuhnya" bagi kabupaten/kotamadya untuk mengelola SDA dan BA masih sangat tidak sebanding dengan "kewajiban sepenuhnya" untuk menyelesaikan segala macam akibat yang muncul dari SDA dan BA tersebut.

Oleh karena itu diperlukan kajian yang lebih mendalam tentang segala upaya, yang bersifat integratif maupun fragmentatif, dalam mengelola SDA maupun $\mathrm{BA}$, sehingga pengertian otonomi daerah dapat didudukkan posisinya secara lebih konstruktif dan proporsional. Untuk itulah paper ini disampaikan agar diskursus tentang pengelolaan SDA yang dikaitkan dengan otonomi daerah tidak seluruhnya mengedepankan posisi bupati atau walikota sebagai satu-satunya panglima atau penguasa sumber daya alam di daerahnya.

Upaya pengelolaan SDA yang integratif dimaksudkan sebagai upaya terpadu yang bersifat hierarkis, baik secara nasional maupun global. Upaya integratif ini dianggap penting bukan saja karena sekarang adalah jamannya globalisasi, melainkan terutama sekali karena umat manusia memang kenyataannya hidup dalam satu planet yang sama, yaitu bumi. Terlebih lagi juga karena planet bumi tersebut berada pada galaksi yang sama, sehingga mestinya upaya integratif tidak saja berlevel global melainkan juga bersifat universal.

Sedangkan upaya yang fragmentatif adalah yang berkait dengan otonomi daerah, atau konsep-konsep penanganan partisipatoris baik di tingkat kewilayahan yang paling bawah hingga kecamatan dan kelurahan, maupun yang bersifat institusional seperti lembaga swadaya masyarakat (LSM), adat-istiadat, manipulasi nilai-nilai mitologi atau local-genius yang pernah dikenali dalam rekayasa preservasi dan konservasi SDA.

Studi kasus deforestasi di Brazil dianggap dapat mewakili penjelajahan mengenai komparasi penanganan integratif dan fragmentatif terhadap SDA (terutama dalam hal pengelolaan hasil hutan) karena kasus tersebut merupakan kasus paling parah di dunia. Dengan level seperti ini, kasus deforestasi (penggundulan hutan) di Brazil merupakan pengetahuan "elementer" bagi para pengambil keputusan dalam pengelolaan SDA di muka bumi ini. Perlu juga diketahui bahwa, kalau Brazil adalah bangsa "penggundul" hutan nomor satu di dunia maka Indonesia adalah yang nomor dua. Oleh karena itu, belajar tentang kasus Brazil, di samping merupakan materi wajib yang "elementer" itu, sesungguhnya bak belajar tentang diri kita sendiri. 
Untuk memudahkan perbincangan tentang kasus Brazil ini, ada baiknya dimulai dengan sejumlah pertanyaan berikut ini: apa yang menyebabkan terjadinya deforestasi di Brazil sebagai kasus paling buruk sedunia ?; upaya integratif dan fragmentatif macam apa yang pernah diterapkan pada kasus deforestasi di Brazil tersebut ?; manfaat apa yang dapat kita petik sebagai hikmah dalam penanganan hal serupa di negeri kita; tantangan, hambatan dan peluang apa saja yang diperkirakan muncul ketika konsep Brazil tersebut diimplementasikan di Indonesia?

\section{PEMBAHASAN}

\section{DEFORESTASI DI BRAZIL}

Deforestasi (penebangan hutan secara liar maupun legal, yang dalam istilah vulgarnya disebut sebagai "penggundulan" hutan), sebenarnya merupakan persoalan lokal tetapi mempunyai dampak global. Saat ini, hutan tropis Amazon di Brazil menjadi sorotan internasional dalam kaitannya dengan fenomena pemanasan planet bumi. Pada tahun 1991, pernah diprediksikan bahwa sangat mungkin hanya sejumlah kecil hutan di daerah terpencil saja yang tersisa dan kira-kira seperempat dari jumlah spesies di muka bumi ini yang bisa bertahan 50 tahun ke depan (Bisnwanger, 1991). Tingginya tingkat penggundulan ini memancing perhatian publik untuk juga membicarakan tentang sejumlah isu berbagai masalah lingkungan, semacam kepunahan keanekaragaman hayati (biodiversity) dan pemanasan global (global warming).

Faktor-faktor eksternal lingkungan ini telah melibatkan secara langsung kebijakan perpajakan pemerintah Brazil, sistem insentif perpajakan, undangundang alokasi pertanahan, dan sistem perkreditan pertanian. Secara keseluruhan, gabungan kebijakankebijakan tersebut telah mengakibatkan distorsi ekonomi yang mengorbankan lingkungan melalui peningkatan permintaan dalam bidang pertanian, perluasan padang rumput (untuk peternakan), dan ladang peternakan. Kebijakan pemerintah Brazil tidak hanya menghancurkan lingkungan, melainkan juga mengurangi kesempatan bagi kaum miskin untuk menjadi petani (Binswanger, 1991). Perusahaanperusahaan besar serta merta mengklaim sejumlah besar bidang tanah di tempat-tempat jaringan jalanan telah tersedia bagi mereka untuk mengaksesnya. Masyarakat kecil yang miskin menjadi semakin terdesak jauh ke pedalaman dalam rangka memperoleh tanah yang dapat ditanami, di wilayah yang belum bertuan. Dalam rangka menurunkan tingkat deforestasi, kebijakan-kebijakan semacam ini harus diperbaiki, dan sejumlah undang-undang maupun peraturan baru yang mengatur tentang tata-guna hutan harus segera diberlakukan.

Negara Brazil mencakup kira-kira sepertiga bagian dari seluruh hutan-tropis yang ada di muka bumi, termasuk di antaranya adalah mayoritas hutan-tropis Amazon. Brazil juga merupakan negara dengan kekayaan keanekaragaman hayati terbesar di dunia dengn lebih dari 56 ribu spesies tanaman, 1700 jenis unggas, 695 hewan amphibi, 578 mamalia, dan 651 reptil (Dean, 1997).

Begitu luasnya hutan Amazon tersebut mengakibatkan pengrusakan hutan di Brazil seluas 34.660 kilometer persegi dalam kurun waktu antara tahun 2000 sampai dengan 2005 hanya tercatat sebagai 0,8\% dari seluruh wilayah hutan mereka. Walaupun demikian, deforestasi di Brazil merupakan kasus penggundulan hutan paling buruk dan paling luas nomer satu di muka bumi.

Wilayah hutan terbesar di Brazil terletak di dataran Amazon, yang merupakan mozaik ekosistem dan berbagai jenis tanaman, termasuk mermacam-macam jenis hutan. Wilayah ini merupakan tempat yang paling menderita karena pengrusakan hutan mencapai 600 ribu kilometer persegi dalam dua generasi belakangan ini, atau sekitar 15\% dari total seluruh hutan di Brazil dibabat habis sejak tahun 19709 Williams, 2002). Meningkatnya deforestasi di Amazone bersamaan dengan dibangunnya prasarana jalan raya Trans-Amzone Highway, yang membuka wilayah hutan yang luas itu menjadi ajang usaha bagi pemukim maupun kepentingan komersial. Pada perkembangan selanjutnya, pertumbuhan penduduk di wilayah Amazone, bersamaan dengan meningkatnya 
kegiatan pertanian, mangakibatkan semakin parahnya penggundulan hutan dimaksud. Sampai dengan berakhirnya tahun 1990, deforestasi terhadap hutan primer di Brazil sudah mencapai 35 persen.

Kajian mutakhir mengenai hal ini mencatat bahwa angka di atas adalah kasus di luar kebakaran hutan dan penebangan kayu. Penelitian yang dilakukan oleh The Woods Hole Research dan Departemen Ekologi Global dari the Carnegie Insitution menunjukkan bahwa menurunnya mutu kehutanan sejajar dengan lajunya pembabatan hutan. Hal ini mempersulit para ahli ekologi mengingat menurunnya mutu hutan akan menurunkan tingkat keanekaragaman hayati dan dikhawatirkan juga akan punah bersamaan dengan punahnya hutan. Penyempitan luas hutan juga menjadi amat rentan terhadap pembakaran hutan.

Di banyak negara tropis, terjadinya deforestasi biasanya diakibatkan oleh rendahnya pengetahuan para pengelola hutan, terutama para warga penghuni tradisionalnya. Di Brazil, kasus semacam itu terhitung hanya sebesar sepertiga saja. Sebagian besar penyebab gundulnya hutan lebih pada pembabatan untuk peternakan bagi kepentingan komersial, kebijakan pemerintah yang salah, proyek-proyek dari Bank Dunia yang tidak tepat, dan eksploitasi komersial lainnya terhadap hasil hutan. Untuk meningkatkan kepedulian terhadap realitas deforestasi di Brazil, pemahaman tentang berbagai penyebab ini sangat penting untuk digaris bawahi. Upaya yang semata-mata ditujukan bagi pembangunan kesejahteraan penduduk lokal akan mengabaikan penyebab yang lebih utama dari peristiwa deforestasi di Brazil ini.

Penggundulan hutan di Brazil amat kuat berkait dengan persoalan kesehatan ekonomi negara tersebut: menurunnya deforestasi pada tahun 1988-1991 berkait secara langsung dengan menurunnya perekonomian Brazil pada saat yang sama, sedangkan meroketnya tingkat deforestasi pada tahun 1993-1998 sejajar dengan pertumbuhan ekonomi yang sangat cepat pada saat itu (Williams, 2002). Di masa-masa yang sulit, para peternak dan developer tidak memiliki cukup uang ntuk mengembangkan usahanya, sedangkan pemerintah telah kehabisan uang untuk membiayai sarana jalan raya dan program pemukiman.

Sejumlah kecil pemilik tanah melakukan pembabatan hutan Amazon untuk kepentingan peternakan. Beberapa wilayah tersebut ditanami rumput savana Afrika untuk pakan ternak mereka. Dalam banyak kasus, terutama pada saat inflasi tinggi, hutan dibabat untuk kepentingan investasi. Ketika harga tanah peternakan meningkat lebih tinggi daripada harga tanah hutan. Hal ini dimungkinkan karena insentif perpajakan lebih mengutamakan bagi tanah garapan daripada hutan alami. Dengan demikiasn, pembabatan menjadi pilihan utama menghadapi inflasi semacam itu.

Kebijakan perpajakan semacam itu, bersamaan dengan program-program pertanian dan pemukiman yang disubsidi oleh pemerintah, menambahkan semakin parahnya deforestasi di Amazon. Dari beberapa kajian yang pernah dilakukan, setidak terdapat 6 (enam) penyebab utama terjadinya deforestasi di Brazil ini, yakni; 1)Buruknya sistem perpajakan; 2)Pembabatan untuk peternakan; 3)Pemukiman dan subsistensi pertanian (semacam transmigrasi); 4)Pembangunan infrastruktur; 5)Pertanian Komersial, dan 5)yang terakhir, adalah industri perkayuan.

\section{Kebijakan Perpajakan}

Masalah paling utama yang harus diperhatikan terlebih dulu adalah tentang struktur perpajakan mengenai pendapatan di bidang pertanian. Perusahaanperusahaan maupun individual boleh menyisihkan 80\%-90\% pendapatan mereka dari bidang pertanian di luar pendapatan kena pajak berdasarkan beberapa provisi pajak tertentu. Lalu muncul dua persoalan: seorang individu bisa dikenakan 10\% pajak terhadap hasil kotor pertaniannya, atau seluruh biaya pengembangan modalnya bisa diperhitungkan dari pendapatan pertaniannya. Modal tetap, hewan, bangunan dan permesinan bisa dimasukkan secara penuh dalam laporan tahun pertama maupun tahuntahun berikutnya (Campari, 2005). Dalam sistem semacam ini, lebih $80 \%$ pendapatan bisa dipisahkan dari perpajakan. Permintaan akan pertahanan 
meningkat sangat tajam, mengingat proyek-proyek pertanian menjadi sangat menarik bagi para pemodal perusahaan maupun perorangan.

Sistem ini jelas mengorbankan kaum miskin, karena tingkat perpajakan yang rendah akan serta merta dikapitalisasi dengan harga tanah, yang mencerminkan tingginya harga tanah, yang menyengsarakan para petani miskin di Brazil karena tak mampu untuk beli tanah pertanian. Hal ini memaksa mereka untuk berpindah terdesak ke hutan di bagian yang lebih dalam, untuk memeproleh tanah yang lebih murah, atau yang tak bertuan, yang pada gilirannya seolah mengesahkan aturan untuk meningkatkan penggundulan hutan.

Pada tahun 1991, boleh dianggap hanya sedikit tanah yang tak bertuan mengingat banyak perusahaan besar yang membangun prasarana jalan untuk memanfaatkan kemudahan perpajakan Brazil itu. Cara paling populer untuk dapat memperoleh sebidang tanah adalah dengan penyerobotan. Datang dan tancapkan patok sebagai tanda klaim atas tanah tersebut. Pada tahun 1850, setiap penyerobot tanah akan mendapatkan hak guna tanah seluas 100 hektar setelah yang bersangkutan bertahan setidaknya selama satu tahun. Setelah 5 tahun kemudian, penghuni tanah tersebut baru dapat hak milik atas tanah tersebut (Campari, 2005). Di wilayah yang berbeda (masih di Brazil juga) mempunyai cara yang berbeda dalam hal memberlakukan hak milik tanah serobotan tersebut. Pada umumnya, semua penyerobotan tanah pada akhirnya akan mendapatkan hak milik atas tanah yang bersangkutan. Dalam rangka mengendalikan deforestasi semacam itu, diperlukan sejumlah wilayah hutan yang luas agar dapat dilindungi. Wilayah yang dapat dikuasai oleh individual juga harus segera dibatasi.

Hal tersebut menunjukkan bahwa perpajakan atas tanah yang berlaku di Brazil telah mengakibatkan meningkatkan terjadinya deforestasi. Sistem perpajakan pertanahan di Brazil sebenarnya secara teori sudah tergolong progresif, tetapi karena ada begitu banyak pengecualian kemudahan maka mengakibatkan sistem tersebut menjadi tidak progresif. Masalah- masalah utama yang berkait dengan pajak pertanahan adalah mengenai pengertian penggunaan tanah. Secara garis besar, semakin banyak tanah yang digarap maka semakin sedikit pajak yang dikenakan. Hutan liar, dianggap sebagai tanah yang belum digarap, sehingga dikenakan pajak yang tinggi. Ketika hutan liar itu digarap - entah untu kepentingan apa pun - maka tidak lagi dikenakan pajak.

Ada tiga hal yang perlu diubah dalam sistem lama seperti itu. Pertama, perkecil batas luas tanah bagi individu, dari semula 3000 hektar menjadi 100 - 200 hektar saja. Sedangkan sebuah keluarga bisa memecah wilayah tanahnya yang luas itu kepada tiap anggota keluarga sehingga menjadi kecil tapi banyak. Kedua, perlu ada batas maksimum kepemilikan tanah bagi perusahaan. Yang terakhir, perlu kejelasan tentang tata guna tanah dalam kerangka skema pengelolaan hutan (www.whrc.org/southamerica/index.htm)

Pajak pertanahan dan pendapatan berpengaruh besar terhadap terjadinya deforestasi, tetapi beberapa jenis perpajakan yang lain seperti pajak pertambahan nilai (PPN) dan pajak perdagangan, sepertinya tak berkait dengan penggundulan hutan tersebut. Beberapa keringanan pajak di beberapa wilayah tertentu tercatat sebagai penyebab terjadinya pengrusakan hutan, secara kesuluruhan sistem perpajakan boleh dikatakan baik-baik saja.

Di beberapa wilayah dan sektor tertentu di Brazil juga turut meningkatkan terjadinya deforestasi ini. The SUDAM (The Superintendency for Amazone Developments, lembaga swasta pembangunan wilayah Amazone), Grand Carajas Program, dan IBDF (Instituto Brasileiro de Desenvolmento Florestal) merupakan program-program perusahaan yang memperoleh insentif perpajakan. Sebagai salah satu contoh, program SUDAM menawarkan semacam kerjasama dalam menyediakan skema pajak prekreditan bagi pembangunan peternakan berskala besar di wilayah Amazon. Tujuannya untuk memperbaiki perekonomian lokal, tetapi yang terjadi adalah pengrusakan hutan, dan menelan banyak biaya (menghabiskan lebih dari US\$1 milyar dalam kurun waktu tahun 1975 sampai dengan 1986) (Anderson, 1990: 1191 - 1205). 
Intinya adalah, bahwa pajak di Brazil itu terlalu murah. Tingkat suku bunga resmi perkreditan adalah negatif sampai dengan tahun 1991. Suku bunga di bidang pertanian lebih rendah daripada di sektorsektor non-pertanian. Perbedaan tingkat suku bunga ini juga turut mendorong kenaikan harga tanah, sehingga petani miskin tak dapat menjangkau harga tanah dan pada akhirnya terdesak ke hutan pedalaman dalam rangka mencari tanah tak bertuan. Sistem prekreditan semacam ini mendorong terjadinya pengrusakan lingkungan, karena menciptakan mekanisme kerja yang mengurangi jumlah tenaga kerja atau tidak padat karya.

\section{Pembabatan Hutan Untuk Peternakan}

Peternakan sapi, baik untuk produksi susu maupun pedaging, merupakan penyebab utama bagi deforestasi di Amazon Brazil. Hal ini sudah berlangsung sejak tahun 1970-an, angka resmi dari pemerintah menunjukkan 30\% dari deforestasi yang terjadi pada tahun 1966 sampai dengan 1975 adalah disebabkan oleh sektor peternakan ini (www.rainforestportal.org/ issues/2007/01/alert_brazil_approves_deforest.asp) Bahkan catatan yang lebih mutakhir menunjukkan perkembangan yang lebih buruk. Menurut catatan CIFOR (the Center for International Forestry Research, pusat riset kehutanan internasional, yang bermarkas di Bogor) bahwa antara tahun 1990 - 2001 prosentase impor daging olahan Eropa dari Brazil meningkat dari $40 \%$ menjadi $70 \%$, dan pada tahun 2003 , untuk pertama-kalinya dalam sejarah, pertumbuhan produksi peternakan di Brazil (yang $80 \%$-nya terdapat di Amazone) sebagian besar adalah untuk memenuhi kebutuhan ekspor.

Ada beberapa faktor yang mendorong lompatan pertumbuhan produk peternakan di Brazil tersebut: $\S$ Devaluasi Mata Uang; devaluasi mata-uang Brazil (real) terhadap dollar Amerika (US\$) mengakibatkan harga daging sapi menjadi dua kali lebih besar dalam real, sehingga mendorong para peternak memperluas lahan mereka dengan mengorbankan hutan tropis. Melemahnya matauang real juga menjadikan harga daging asal Brazil ini sangat kompetitif di pasar internasional.

$\S$ Pengawasan Terhadap Penyakit Kuku dan Mulut (pada sapi); keberhasilan penanggulangan kedua penyakit itu di Brazil telah meningkatkan permintaan dan melambungkan harga daging sapi dari Brazil.

$\S$ Infrastruktur; sarana dan prasarana jalan raya telah menyediakan para developer (pengembang) dan peternak(rancher) mengakses wilayah hutan di Amazon yang sebelumnya tak tersentuh. Infrastruktur juga telah banyak menghemat beaya pengiriman dan pengepakan produk mereka.

$\S$ Tingkat Suku Bunga; tanah hutan-tropis sering dimanfaatkan untuk kepentingan-kepentingan dengan tujuan spekulatif. Ketika harga tanah peternakan melampaui harga tanah hutan biasa, pembabatan hutan menjadi pilihan penting untuk menghadapi inflasi. Pada saat inflasi tinggi, apresiasi harga tanah peternakan dan produk yang dihasilkannya (susu dan daging) bisa melampaui tingkat suku bunga bank.

$\S$ Jangka Waktu Hak Guna/Milik Pertanahan; di Brazil, pemukim dan pengembang bisa memperoleh kepemilikan tanah di Amazone hanya dengan membabat hutan dan menempatkan beberapa ekor hewan untuk peternakan. Sebagai hasil tambahan, peternakan merupakan usaha dengan resiko rendah dibandingkan dengan pertanian yang amat rentan harganya pada waktu panen serta terus menerus diancam oleh hama. Singkatnya, peternakan merupakan "kendaraan utama" untuk pemilikan tanah di Amazone.

Beberapa pihak ada yang mengusulkan bahwa sertifikasi di bidang pertanian diharapkan dapat dijadikan salah satu alat pengendalian pembabatan hutan di masa depan.

\section{Pemukiman dan subsistensi pertanian}

Sebagian proses deforestasi dipicu oleh kegiatan subsistensi petani miskin yang memaksa mereka untuk tinggal di daerah perhutanan. Di Brazil, setiap "penyerobot" tanah (orang mendapatkan tanah dari 
membabat/membuka lahan di hutan) akan memperoleh hak (semacam hak guna) untuk melanjutkan pemanfaatan tanah yang tak bertuan tersebut, dengan tinggal bermukim di tempat itu untuk sekurang-kurangnya selama satu tahun satu hari. Setelah tinggal selama lima tahun kemudian, "penyerobot" tanah tersebut akan memperoleh sertifikat hak milik dan berhak menjualnya kepada pihak lain. Hingga pertengahan tahun 1990-an, keadaan ini diperburuk dengan peraturan pemerintah yang memungkinan setiap "penyerobot" untuk mendapatkan lagi hak milik atas tanah (baru) tiga kali lebih luas daripada sebelumnya.

Para petani miskin membuka lahan hutan dengan cara membakarnya dan setiap tahun satelit pencitraan menangkap puluhan ribu titik api bertebaran di seluruh wilayah Amazone( www.scidev.net/News/ index.cfm?fuseaction=readNews\& itemid=3081 \&language=1). Beberapa tanaman semak dibersihkan, pepohonan ditebang. Wilayah itu didiamkan sementara waktu supaya kering, lalu dibakar. Lahan tersebut lalu ditanami pisang, padi, kopi dan sebagainya. Setelah satu atau dua tahun, produktifitas lahan tersebut berkurang, lalu para petani itu akan membuka lahan baru lagi untuk lahan pertanian jangka pendek semacam itu. Lahan yang lama, yang sudah tidak subur lagi, dimanfaatkan untuk ditanami rumput bagi pasokan pakan ternak skala kecil-kecilan, atau dibiarkan saja menjadi tanah gundul yang liar.

Antara tahun 1995 dan 1998, pemerintah telah memberikan tanah di Amazone kepada setidaknya 150 ribu kepala keluarga (KK). Sebagian besar deforestasi yang terjadi pada tahun bersangkutan diduga disebabkan oleh program pemukiman petani semacam itu.

\section{Pembangunan Infrastruktur}

Konstruksi jalan raya di Amazon memicu maraknya deforestasi. Jalanan menyediakan siapa saja untuk dengan mudah dapat mengakses hasil hutan (kayu) maupun hasil tambang, dan mengakibatkan eksploitasi batas-batas hutan oleh petani miskin yang tak memiliki tanah. Jalan raya Trans-Amazonia merupakan proyek pembangunan ekonomi yang amat ambisius yang pernah mereka lakukan, dan sekaligus merupakan kekeliruan yang amat besar. Pada tahun 1970-an, pemerintah Brazil merencanakan membangun jalan raya sepanjang kurang lebih 2000 mil yang akan membelah hutan belantara Amazon yang luas itu, dengan membuka lahan hutan tropis untuk: 1)pemukimam petani miskin dari kepadatan pendudukan di wilayah utara; dan 2)membangun industri perkayuan dan pertambangan. Setiap pemukim (semacam transmigran) mendapatkan lahan seluar 250 are, gaji selama enam bulan, dan kemudahan untuk memperoleh pinjaman sektor pertanian sebagai imbalan bagi kesediaan mereka untuk tinggal di sepanjang jaringan jalan raya TransAmazone tersebut dengan menggarap tanah di sekitar hutan tropis menjadi lahan pertanian. Rencana itu bertarif US\$65.000 (pada tahun 1980-an) sumbangan bagi tiap kepala keluarga, suatu jumlah yang cukup berat bagi perekonomian Brazil, yang merupakan salah satu negara berkembang pada waktu itu.

Proyek tersebut sudah terlihat kedodoran sejak awal. Sedimen tanah di dataran Amazon tidak mendukung stabilitas konstruksi jalanan tersebut dan terancam banjir disetiap musim hujan, sangat menghambat arus lalu lintas dan mengakibatkan rusaknya hasil bumi. Hasil panen bagi para petani sangat buruk mengingat lahan pertaniannya terlalu cepat mandul, dan lahan hutan baru harus dibuka setiap tahunnya. Penebangan kayu masih sangat sulit, karena jenis kayu komersial tersebar di berabagai titik yang sulit dicapai. Erosi yang sulit dikendalikan, lebih dari 40 ton tanah per hektar bergeser sesudah hutan dibabat. Para pemukim (transmigran) tak terbiasa dengan urusan perbankan, sehingga mudah terbujuk oleh kredit murahan lalu terjebak dalam hutang yang mencekik.

Dapat ditambahkan lagi kesalahan aspek ekonomi dan sosial dari proyek ini, yaitu mengenai biaya lingkungan jangka panjang. Setelah selesai pembangunan jalan raya Trans-Amazonia tersebut, deforestasi di Brazil melonjak pada level yang belum pernah terbayangkan sebelumnya, dan banyak sekali 
potongan-potongan lahan hutan yang baru dibabat yang dibangun untuk subsistensi pertanian dan peternakan. Proyek Trans-Amazonia ini merupakan contoh pengrusakan lingkungan besar-besaran yang diakibatkan oleh pembangunan jalan di hutan belantara tropis. Sementara itu, pembangunan dan perbaikan jalan raya tersebut masih berlangsung hingga saat ini. Perbaikan pada permukaan jalanan tersebut akan berpengaruh pada sifat hutan tropis Amazone, dan sejumlah kontraktor Cina telah ikut membangun jalanan tersebut serta ambil bagian dalam deforestasi yang dimaksud.

\section{Komersialisasi Pertanian}

Saat ini, kedelai juga merupakan kontributor utama dari penyebab terjadinya deforestasi di Amazon Brazil. Dengan berhasil ditemukannya beberapa varietas baru kedelai oleh para ilmuwan Brazil, yang tumbuh subur pada iklim hutan tropis, Brazil menempatkan diri sebagai pengekspor kedelai terbesar di dunia (terutama dengan tujuan Amerika Serikat). Tingginya harga kedelai di pasar dunia juga menjadi penyebab meningkatnya penanaman kedelai di Brazil.

Philip Fearnside, seorang anggota Institute Nasional untuk Riset Amazon di Manaus menjelaskan bahwa: ladang kedelai mengakibatkan deforestasi secara langsung. Bahkan selalu memerlukan lahan baru yang luas, padang rumput, dan hutan transisi, dengan demikian juga senantiasa mendesak petani pembakar hutan untuk masuk lebih jauh ke pedalaman hutan. Pertanian kedelai juga merupakan faktor pendorong utama bagi ekonomi dan politik untuk pembangunan jalan dan infrastruktur lainnya, yang pada giliranya juga akan mengakibatkan deforstasi oleh pihak lain lagi (Jurnal Science, 21 Mei 2004).

\section{Industri Perkayuan}

Dalam teori, pengambilan hasil hutan dalam bentuk kayu (logging) di Amazone dikontrol secara ketat dimana perusahaan perkayuan hanya boleh melakukan penebangan hutan di wilayah yang sudah direncanakan. Namun demikian, terdapat sejumlah bukti kuat bahwa pembalakan liar (illegal logging) terjadi di mana-mana di Brazil. Dalam beberapa tahun belakangan ini, Ibama (sebuah agen pembelaan lingkungan di Brazil) telah membuat sejumlah ukuran terhadap perusahaan yang melakukan pembalakan liar, termasuk yang terjadi pada tanggal 13 September 2003 dimana 17 orang ditahan yang didakwa telah melakukan penebangan liar seluas 10 ribu hektar (www.globalchange.umich.edu)/globalchange2/ current/lectures/deforest/deforest.html.)

Penebangan hutan terkait erat dengan pembangunan sarana jalan raya. Studi yang dilakukan oleh the Evironmental Defense Fund menunjukkan bahwa wilayah-wilayah yang secara terencana ditebang, delapan puluh persen di antaranya adalah lahan yang kemudian dihuni dan yang sebelumnya dibabat oleh para pemukim liar daripada hujan tropis yang masih asli karena kesulitan pengangkutan. Jaringan jalan untuk logging memudahkan para pemukim untuk dapat mengakses hujan tropis dalam rangka memenuhi kebutuhan untuk kayu bakar, bahan bangunan atau kebutuhan pertanian sementara.

\section{SEBAB-SEBAB LAIN TERJADINYA DEFORETASI}

Kalau masih dianggap perlu untuk menambahkan sejumlah penyebab lain dalam meningkatkan terjadinya deforestasi di Brazil, memang masih ada sejumlah peristiwa yang perlu dicatat untuk itu.

Pertama, secara historis, proyek PLTA telah menenggelamkan sejumlah besar area hutan tropis Amazone. Bendungan (Dam) Balbina telah membenamkan 2400 kilometer persegi wilayah hutan tropis. Dalam tiga tahun pertama pengoperasian PLTA Balbina ini diperkirakan telah menghasilkan 23.750.000 ton karbon dioksida (CO2) dan 140.000 ton metana ( $\mathrm{CH} 4)$, keduanya berpotensi mengeluarkan efek gas rumahkaca yang berpengaruh pada perubahan iklim global .

Kedua, pertambangan juga tercatat sebagai penyumbang kerusakan lingkungan di dataran Amazone. Selama tahun 1980-an, lebih dari 100 ribu pemodal ramai-ramai menyerbu provensi Para ketika ditemukan deposit emas dalam jumlah besar di sana, sementara para penambang gelap masih berkeliaran di 
provinsi Roraima dekat perbatasan dengan negara Venezuela. Biasanya, para penambang liar membabat hutan untuk keperluan bahan bangunan, kayu bakar dan perlengkapan pertanian.

Sebab terjadinya deforestasi yang lain adalah kebakaran, yaitu kebakaran yang diakibatkan oleh alam, bukan faktor kesengajaan manusia. Atau juga yang diakibatkan oleh dampak pembukaan lahan, yang semula direncanakan dalam jumlah terbatas tetapi kenyataannya merembet kemana-mana dan menghancurkan banyak fasilitas lainnya, khususnya terjadi pada musim kering seperti yang pernah terjadi pada tahun 2005 yang lalu. Api sulit dipadamkan hingga selama tiga bulan penuh. Kebakaran itu menimbulkan 500 juta ton karbon, 47 juta ton karbon monoksida dan partikel lain serta dinitroksida $(\mathrm{N} 2 \mathrm{O})$.

\section{UPAYA-UPAYA PENANGGULANGAN DAN PEMULIHAN}

Seperti yang telah disinggung dalam judul paper ini, upaya penanggulangan ataupun pemulihan/ perbaikan terhadap kerusakan hutan, sebagai salah satu bentuk pengelolaan sumber daya alam(SDA) menjadi perlu dikaji lebih mendalam, terutama dalam pengertian integratif, yaitu upaya yang didasarkan pada struktur hirarki organisasi lokal-global, dan yang bersifat fragmentatif, dalam pengertian studi komparasi terhadap upaya-upaya yang dilakukan pada tingkat yang paling bawah (horisontal).

\section{PENGELOLAAN YANG INTEGRATIF}

Baik di Brazil maupun di Indonesia, bahkan di hampir semua negara di dunia, kebijakan pengelolaan SDA secara garis besar terletak pada wewenang pemerintah nasional (atau federal). Pemerintah daerah (provinsi ataupun kabupaten/kotamadya), atau negara bagian, merupakan pihak yang berwenang di bagian ilir. Begitu juga pihak luar negeri, baik lembaga internasional ataupun negara asing, tak dapat sepenuhnya memiliki wewenang langsung terhadap kebijakan pengelolaan SDA secara keseluruhan.

Namun demikian perlu digarisbawahi bahwa, walaupun lembaga internasional seolah tak memiliki wewenang secara langsung dalam penanganan deforestasi tetapi (sebaliknya) lembaga internasional tak dapat dikesampingkan begitu saja kepedulian dan pemikiran mereka mengenai lingkungan hidup. Lembaga semacam PBB misalnya, mempunyai andil sangat besar dalam mempromosikan pengelolaan SDA yang berkelanjutan, yang dianggap baik bagi umat manusia dengan segala hasil peradabannya. Kalau pemda merupakan pelaku ilir dalam pengelolaan SDA maka lembaga internasional dapat dianggap sebagai penghulu bagi tiap strategi penanganan SDA.

Sebagai contoh adalah upaya para pemimpin dunia yang berkumpul di Markas PBB, New York dua tahun lalu untuk mengikuti Millenium Summit mengakui sejumlah fakta buram. Mereka memutuskan untuk berusaha keras untuk menghapuskan kemiskinan global pada tahun 2015. Mereka juga bertekad membebaskan generasi mendatang dari ancaman akibat eksploitasi sumber daya alam secara habis-habisan oleh kegiatan manusia sebelumnya.

Ini yang dianggap sebagai "Pembangunan Berkelanjutan" yang istilahnya diperkenalkan World Conservation Union, NGO internasional bermarkas di Swiss, namun dipopulerkan oleh Komisi Brundtland, yang mendefinisikannya secara formal dalam laporan khusus mengenai lingkungan dan pembangunan, Our Commmon Future tahun 1987. KTT Johannesburg atau Konferensi Tingkat Tinggi mengenai Pembangunan Berkelanjutan (World Summit on Sustainable Development, WSSD) bertujuan untuk menemukan cara-cara yang bisa diimplementasikan guna menanggapi dua tantangan besar, kehidupan yang lebih baik dari semua manusia, sekaligus menjaga dan melindungi lingkungan yang menopang kehidupan di Bumi," ujar Sekjen PBB Kofi Annan, dalam pidato tertulis pada Pertemuan IV Komite Persiapan (PrepCom IV) WSSD di Bali.

Sekjen WSSD Nitin Desai menolak mengatakan bahwa WSSD merupakan kelanjutan KTT Bumi tahun 1992 atau Konferensi Internasional mengenai Pembiayaan Pembangunan di Monterrey, Meksiko, Maret tahun 2002. WSSD dibangun di atas pencapaian kedua konferensi besar itu, tetapi mencoba 
mengimplementasikan sasaran yang disepakati dalam berbagai konferensi, termasuk yang diadopsi oleh para pemimpin dunia di Millenium Summit di bawah payung "Pembangunan Berkelanjutan".

WSSD bertujuan untuk bergerak dari sekadar komitmen ke dalam tindakan nyata. Sejak Konferensi Dunia I mengenai Lingkungan Manusia di Stockholm, Swedia, tahun 1972, terdapat lebih 500 perjanjian mengenai lingkungan, tetapi lemah pelaksanaannya. Dalam kerangka "Pembangunan Berkelanjutan", WSSD memusatkan perhatian pada masalah kemiskinan, konsumsi berlebih dan gaya hidup tak berkelanjutan. Karena Agenda 21, cetak biru prinsipprinsip Pembangunan Berkelanjutan yang dihasilkan dalam KTT Bumi 1992, terlalu fragmented sehingga sulit implementasinya, Sekjen PBB melihat lima masalah khusus terkait dengan perhatian WSSD yang bisa ditangani secara bersama.

Pertama, masalah air dan sanitasi. Saat ini lebih satu milyar penduduk di dunia hidup tanpa air bersih. Dua kali jumlah itu tidak memiliki sanitasi memadai dan lebih tiga juta orang setiap tahun mati oleh penyakit yang disebabkan tidak adanya air bersih. Banyak kota kehilangan sekitar 40 persen dari pasokan air bersih.

Kedua, energi. Konsumsi energi akan tumbuh dua persen per tahun sampai tahun 2020. Konsumsi energi per kapita di negara maju setara 6,4 ton ton bahan bakar minyak per tahun, 10 kali lebih tinggi dibandingkan per kapita di negara berkembang. Subsidi pemerintah di dunia untuk energi 200 milyar dollar per tahun, 30 milyar di antaranya di AS. Emisi global Karbon Dioksida (CO2) dan gas rumah kaca lainnya yang berpengaruh pada perubahan iklim dunia naik dua kali lipat tahun 1965-1998.

Ketiga, produktivitas pertanian. Degradasi lahan akibat perubahan iklim, kekeringan dan banjir berdampak pada sekitar duapertiga lahan pertanian dunia, menyebabkan produktivitas pertanian menurun drastis. Di Afrika, jutaan orang selalu diancam kelaparan, dan kemiskinan absolut.

Keempat, kesehatan. Kegiatan pembangunan selalu berdampak pada lingkungan dan penyebab berbagai masalah kesehatan. Sekitar 11 juta anak di bawah usia lima tahun, sebagian besar di negara berkembang, setiap tahun meninggal akibat penyakit-penyakit yang disebabkan pencemaran air dan udara. Perubahan iklim yang menyebabkan banjir dan kekeringan sangat berpengaruh kepada kesehatan manusia. Perkembangan siklus hidup parasit usus dan vektor penyakit berkaitan dengan perubahan temperatur. Malaria, yang 90 persen terdapat di Afrika sub-Sahara, membunuh sekitar satu juta orang per tahun. Kerugian ekonominya diperkirakan 12 milyar dollar per tahun.

Kelima, keragaman hayati dan manajemen ekosistem. Penyebab degradasi lingkungan tidak langsung terlihat. Penggundulan hutan di bagian atas menyebabkan banjir di bagian bawah. Kadang penyebabnya jauh dari sumber masalah. Naiknya emisi gas rumah kaca di negara industri membuat naiknya permukaan air laut di Pasifik Selatan.

Intergovernmental Panel on Climat Change (IPCC) menyatakan, kenaikan permukaan laut 10-20 cm dalam 100 tahun terakhir, menyebabkan sedikitnya 46 juta orang per tahun dilanda banjir akibat terjangan badai dan menenggelamkan pulau-pulau kecil. Dalam 10 tahun ini Bumi kehilangan sekitar 94 juta hektar hutan. Angka deforestasi di negara berkembang mencapai empat persen. Kegiatan manusia merusak lebih separuh sistem ekosistem pesisir. Sekitar 80 persen pencemaran laut disebabkan sumber di daratan. Penggurunan mengancam kehidupan lebih satu milyar penduduk di 100 negara. Degradasi ekosistem merupakan penyebab utama pemiskinan, bencana alam, kelaparan dan penyakit di seluruh dunia.

Meski kelima masalah khusus yang disingkat sebagai WEHAB (water, environment, health, agriculture, biodiversity) itu tampak lebih mudah solusinya, namun persoalan sebenarnya sangat rumit. Saat ini terdapat sejumlah perjanjian perdagangan intenasional memiliki implikasi langsung pada perlindungan kesehatan, seperti Sistem Perdagangan Berkaitan dengan Hak Milik Intelektual (TRIPS) terhadap vaksin dan obat esensial. Dengan sistem ini, orang miskin, khususnya penderita HIV/AIDS tak bisa membeli obat paten karena terlalu mahal, sementara pengembangan obat 
generik yang jauh lebih murah, dihambat.

Dalam Konferensi Menteri IV WTO di Doha, Qatar, Oktober 2001, masalah ini menjadi mata perundingan yang alot. Memang akhirnya dicapai kesepakatan agar pelaksanaan TRIPS tidak menghambat negara memberikan pelayanan kesehatan pada masyarakat, tetapi esensi perjanjian TRIPS belum berubah. Selain itu ada perjanjian internasional untuk ukuran-ukuran Kesehatan, Kebersihan dan Phytosanitary (SPS) serta Hambatan Teknis untuk Perdagangan (TBT) yang akan berdampak pada kebijakan nasional untuk pangan, termasuk regulasi pestisida dan bioteknologi. (www.cifor.cgiar.org/ publications/pdf_files/media/Amazon.pdf)

Dalam masalah sanitasi dan air bersih, kerja sama dengan sektor swasta berpotensi menutup akses rakyat miskin pada sumber air bersih. Bank Dunia memperkirakan kebutuhan investasi sebesar 600 milyar dollar dalam 10 tahun ini. Di bidang pertanian, ada perjanjian mengenai pertanian yang berstandar ganda terhadap negara maju. AS misalnya, memberikan subsidi pertanian melalui Farm Bill yang baru, sebesar 170 milyar dollar selama 10 tahun. Sementara, AS menuntut penghapusan proteksi pertanian di negara lain.

Di bidang energi, persoalan perubahan iklim berkaitan dengan pengurangan emisi gas-gas rumah kaca, utamanya CO2. Kerangka PBB untuk Konvensi Perubahan Iklim yang secara politis dijabarkan dalam Protokol Kyoto, mensyaratkan negara yang meratifikasi mengurangi emisi CO2 sampai target yang disepakati. Eratnya hubungan bisnis dan kekuasaan menyebabkan AS, penyumbang seperempat emisi gas $\mathrm{CO} 2$ dunia, menolak Protokol Kyoto.

Ada sekitar 75 persen Rancangan Plan of Implementation disepakati di Bali, namun banyak pihak skeptis perundingan di Johannesburg akan menyepakati 25 persen sisanya. Bagian itu paling krusial dan melibatkan banyak kepentingan; tak hanya negara maju beserta korporasi-korporasi internasionalnya, tetapi juga kepentingan pemerintah negara berkembang yang sebagian dikenal korup. Oleh karena itu, persoalannya terus berkisar pada kepentingan parsial, yang berarti
Bumi tidak ditempatkan di depan kehidupan; kehidupan di depan manusia; dan tidak peduli kepada mereka yang tertinggal, maka konsep "Pembangunan Berkelanjutan” perlu dipertanyakan.

Penerima penghargaan PBB di bidang lingkungan, Global 500 Award, Bruce Rich, dari Environmental Defence Fund (EDF) menyatakan bahwa, konsep itu sebenarnya mengandung kontradiksi satu sama lain karena lingkungan dan pembangunan adalah seperti anak panah yang meluncur ke jurusan berbeda. Pembangunan yang mengeksploitasi lingkungan dan sumber daya alam tidak bisa ditahan, nafsu manusia untuk menguasai tak bisa dibendung dan cenderung hanya diyakini satu standar mengenai kemajuan dan modernitas, yang mengacu pada masyarakat konsumeris.

Sedangkan untuk ruang lingkup nasional Brazil, dalam rangka menghadapi deforestasi yang dahsyat itu, mereka juga memiliki sejumlah besar wilayah yang luas yang dilindungi, dan selalu dikembangkan dibawah Amazone Region Protected Areas (APRA). Melalui rencana 10 tahun menciptakan jaringan seluas 190 ribu mil-persegi perlindungan hutan untuk cadangan penggunaan yang berkelanjutan. Mereka juga menyisihkan beberapa bigang lahan hutan, kira-kira $12,5 \%$ dari jumlah total pertanahan di Brazil dan 26,4 \% dari dataran Amazon, untuk pemukiman penduduk asli, yang terdiri dari kurang-lebih 450 ribu suku Indian atau 0,25\% dari jumlah warga-negara Brazil. Reservasi untuk penduduk asli ini tertuang secara tegas dalam Konstitusi 1988, telah membantu para pemukim asli tersebut untuk dapat berkumpul kembali setelah berabad-abad mereka terpisah maupun hilang. Sebagian besar, lebih dari 60\% dari suku Indian Brazil tinggal di dataran Amazon (The Economist, February $2^{\text {nd }} .2006$ ).

Wilayah perlindungan ini sangat tidak populer bagi petani miskin, pemilik tanah dan developer, yang merasa telah berusaha keras membangun area baru di wilayah yang secara sengaja mereka perjuangkan kelestariannya, terutama hutan mahoninya. Apapun alasannya, menurut sejumlah penelitian yang dilakukan oleh the Woods Hole Research Center dan 
Institudo de Pesquisa Ambiental da Amazona, menunjukkan bahwa wilayah perlindungan telah berperan menurunkan laju deforestasi. Berdasarkan analisis kuantitatif terhadap data satelit, penelitian itu menyimpulkan bahwa deforestasi dan insiden kebakaran hutan menurun secara signifikan di dalam hutan primer dan di sekitar hutan lindung tersebut (The Economist, February 2nd. 2006).

\section{UPAYA FRAGMENTATIF}

Dari segi jumlah dan jenis, upaya fragmentatif yang bisa dilakukan untuk mengelola SDA, terutama dalam hal hasil hutan, tentu lebih banyak dan beraneka ragam dibandingkan dengan yang integratif. Hal ini terjadi karena faktor-faktor penyebab pengrusakan hutan sangat mungkin berbeda di tempat satu ke tempat yang lain. Secara teoretik, upaya fragmentatif meliputi konsep-konsep partisipatori dari berbagai pihak di wilayah paling ilir, paling implementatif di lapangan, dalam pengelolaan SDA yang berkelanjutan.

Dalam kasus penanganan deforestasi di Brazil, upaya semacam ini salah satunya dilakukan dengan memanfaatkan penduduk asli dengan teknologi internet. Jauh di daerah terpencil dalam hutan Amazone, suku Indian Amazone memanfaatkan Google Earth, pemetaan Global Positioning System (GPS) dan teknologi lainnya untuk melindungi tanah pemukiman mereka dari ancaman pembalak liar. Suku-suku di Suriname, Brazil dan Colombia memadukan pengetahuan tradisional mereka mengenai hutan tropis dengan teknologi Barat untuk melestarikan hutan dan mengupayakan kesinambungan sejarah dan kelestarian kebudayaan mereka, termasuk mengenai pengetahuan mereka tentang ekosistem hutan tropis dan tanamam obat. Lembaga yang membantu mereka adalah the Amazon Conservation Team (ACT), sebuah lembaga non profit yang bekerjasama dengan penduduk asli untuk melestarikan keanekaragaman hayati, kesehatan dan kebudayaan di hutan tropis Amerika Selatan. Sebuah perusahaan penelitian obat dari Inggris juga ambil bagian dengan perusahaan Brazil untuk mencari obatobatan dari hutan tropis Amazon dan Atlantik (The Economist, February $\left.2^{\text {nd }} \cdot 2006\right)$

\section{KESIMPULAN}

Kasus yang berlangsung di Brazil dapat dijadikan pelajaran penting untuk menangani persoalan serupa di Indonesia. Untuk mengkaitkannya dengan kasus otonomi daerah di Indonesia, analisis tentang kasus deforestasi di Brazil tersebut di atas rasanya tak terlalu sulit sebagai media komparasi. Intinya, secara integratif, pengelolaan SDA tak mungkin dapat begitu saja mengesampingkan lembaga internasional atau luar negeri, karena disamping dampak pengelolaan tersebut sangat mungkin mengganggu kehidupan bangsa lain, juga karena pembiayaan konservasi ataupun maintainance SDA sering memerlukan bantuan mereka. Mau tak mau model global (atau universal, kalau ada) akan menjadi acuan utama pengelolaan tersebut.

Secara fragmentatif, konsep otonomi daerah, pelibatan masyarakat lokal maupun nilai-nilai adat setempat atau konsep semacam itu, cepat atau lambat, langsung maupun tak langsung, akan mengemuka sebagai salah satu model pelaksanaan pengelolaan SDA di suatu wilayah tertentu. Ide tentang "konsesi untuk konservasi” yang sudah diterapkan di Amazone dan Guyana, bisa saja dilakukan di Indonsia kalau semua pihak mendukungnya (Warta Kebijakan, CIFOR, No.12, Juni 2003). Kombinasi dari keduanya, integratif dan fragmentatif, dapat juga dilakukan seperti contoh pemanfaatan internet oleh suku Indian Amazon di Brazil.***

\section{REFERENSI}

Anderson, Anthony .1990. "Smokestacks in the Rainforest: Industrial Development and Deforestration in the Amazon Basin" dalam World Development, Vol.18, No.9. hal.1191-1205.

Binswanger, Hans P.1991. "Brazilian Politicies that Encourage Deforestration in the Amazon," dalam World Development, Vol.19, No.7, hal.821-829.

Campari, Joao S..2005. The Economics of Deforestation in the Amazone: Dispelling the Myths, New York: Edward Elgar Publisher. CIFOR. 2003. Warta Kebijakan, No.12, Juni.

Dean, Warren .1997. With Broadax and Fireband: The Destruction of the Brazilian Atlantic Forest, San Francisco: University of California Press.

Jurnal Science .2004. 21 Mei

The Economist, February $2^{\text {nd }} .2006$.

Williams, Michael .2002. Deforesting the Earth: From Prehistory to Global Crisis, Chicago: University of Chicago Press.

www.cifor.cgiar.org/publications/pdf_files/media/Amazon.pdf 
www.globalchange.umich.edu/globalchange2/current/lectures/deforest/ deforest.html

www.globalchange.umich.edu/globalchange2/current/lectures/ deforest/deforest.html

www.scidev.net/News/ index.cfm?fuseaction $=$ readNews\&itemid $=3081$ \&language $=1$

www.rainforestportal.org/issues/2007/01/ alert brazil approves deforest.asp 